\title{
26 Research Square \\ Genetic variation in lowland and mountain populations of Tofieldia calyculata and their ability to survive within low levels of genetic diversity
}

\section{Tomáš Vlasta ( $\sim$ vlastat@natur.cuni.cz)}

Charles University: Univerzita Karlova https://orcid.org/0000-0001-7520-8816

\section{Zuzana Mứnzbergová}

Charles University: Univerzita Karlova

\section{Research Article}

Keywords: Genetic diversity, Herbarium specimens, Lowlands, Peripheral populations, Microsatellites, Relict, Tofieldia calyculata

Posted Date: April 16th, 2021

DOl: https://doi.org/10.21203/rs.3.rs-341613/v1

License: (a) (i) This work is licensed under a Creative Commons Attribution 4.0 International License. Read Full License

Version of Record: A version of this preprint was published at Conservation Genetics on March 28th, 2022. See the published version at https://doi.org/10.1007/s10592-022-01439-5. 


\section{Abstract}

Loss of genetic diversity is expected to be a common reason for decline of populations of many rare species. To what extent this is true for populations at the range periphery remains to be explored. Alpine species with peripheral lowland populations are ideal but poorly known model system to address this issue. We investigated genetic diversity and structure of populations of Tofieldia calyculata, species common in central European mountains but highly endangered in lowlands using 17 microsatellite loci.

We showed that lowland populations have lower genetic diversity than mountain populations and they are not clearly differentiated from mountain populations. Species probably survived the last glaciation in refugia in margins of Alps and western Carpathians. Some lowland populations are probably relict as well and contain unique genetic information. Their low genetic diversity is likely the result the of reduction of population sizes, gene flow during the Holocene and selfing. However postglacial colonization is also a case of some lowland populations. Based on data from herbarium specimens from extinct lowland populations, we demonstrated that lowland populations had low genetic diversity also in the past and main part of the genetic diversity was lost due to extinction of whole populations. Within population genetic diversity has not changed since the last century suggesting that these populations are able to survive with low levels of genetic diversity under suitable habitat conditions. This idea is also supported by finding of large viable recent populations with very low genetic diversity. We conclude that lowland populations are unique and deserve adequate conservation.

\section{Introduction}

It is generally assumed that genetic diversity is crucial for long-time persistence of plant populations (Frankham et al. 2010). In the centre of distribution range the populations are expected to be more genetically diverse and less differentiated than populations at the range periphery (Eckert et al., 2008; Hardie and Hutchings, 2010). Need to protect peripheral populations, if the species is common in the centre of the distribution, is controversial (Hunter and Hutchinson 1994; Hardie and Hutchings 2010). Recent studies, however, suggested that peripheral populations may contain high genetic diversity (Wagner et al. 2011, Plenk et al. 2017, Kropf et al. 2020) and can be genetically differentiated from central populations (Reisch et al. 2003, Plenk et al. 2017). These peripheral populations may represent sources of genetic diversity allowing species to cope with changing climatic conditions (Hampe and Petit 2005; Gibson et al. 2009) and a source of possible speciation events (Hardie and Hutchings 2010). Understanding the genetic differentiation among central and peripheral populations is thus crucial for setting priorities in species conservation.

An interesting system with potentially strongly differentiated peripheral and central populations are species common in central European mountains (Alps, Carpathians) with peripheral endangered populations in lowlands of central Europe (Reisch et al., 2003; Štěpánková, 2010, Duwe et al., 2017). In lowlands these species are restricted into scarce primary or secondary open habitats (fens, meadows, dry grasslands, rocks) and are often rare and declining. For setting conservation priorities, it is very important 
to distinguish if the lowland populations are genetically different and relict or if they are genetically depauperate and not differentiated due to being a product of postglacial colonization from glacial refugia situated on the margins of Alps (Schönswetter et al., 2005) or Carpathians (Mráz et al. 2007; Ronikier et al. 2008; Kolár et al. 2016). Genetic diversity of the species with alpine-lowland distribution is poorly understood. Only a few recent studies focused on species with this type of distribution (e.g. Greimler and Dobeš 2000; Lutz et al. 2000; Reisch et al. 2003; Windmaißer et al. 2016; Duwe et al. 2017; Duwe et al. 2018; Knotek and Kolár 2018) with mixed results. Genetic diversity of lowland populations is often reduced due to their isolation and small size (Duwe et al. 2017; Duwe et al. 2018). In other species, lowland populations show no genetic erosion and high levels of genetic diversity probably due to high longevity of individuals and population sizes large enough for long time preservation of genetic diversity (Lutz 2000; Reisch et al. 2002; Reisch et al. 2003; Knotek and Kolář 2018). Evidence for relict status of lowland populations was given by either high genetic diversity and presence of rare alleles (Greimler and Dobeš 2000; Knotek and Kolář 2018) or low within population diversity but high between population differentiation due to their high isolation and bottleneck effects (Reisch et al. 2003).

Low genetic diversity found in some of the lowland populations may have originated by two alternative processes. These populations were always depauperate due to being result of long-distance dispersal after the last ice-age (Wroblewska 2008; Windmaißer et al., 2016). Alternatively, the populations could be relict and their low genetic diversity may be a result of their recent strong size reduction leading to strong genetic drift. Low within population diversity but high differentiation of populations is expected in this scenario (Reisch et al., 2003; Hensen et al., 2010; Vogler and Reisch, 2013). Distinguishing whether the populations are relict and are able to survive with low genetic diversity is important for decision whether it makes sense to protect these populations. Such knowledge can be obtained by exploring genetic structure of populations within the distribution range. Important knowledge can be also obtained by analysis of older samples from herbaria, which can help us to distinguish whether lowland populations have always been impoverished and their low genetic diversity was not the reason for their decline or their genetic diversity has declined during the last century due to human mediated landscape changes. Despite some difficulties resulting from bad quality and fragmentation of old DNA, analysis of old herbarium samples has been recently successfully used in some endangered species to test how much genetic variability was lost in the last decades (Cozzolino et al. 2007; Frey et al. 2017; reviewed by Bieker and Martin 2018).

Using microsatellite markers on samples both from centre mountain and peripheral lowland populations, we compared genetic diversity and composition of lowland and mountain populations of Tofieldia calyculata (L.) Wahlenb., a common plant species in the Alps and western Carpathians, with strongly declining peripheral populations in lowlands of central and north-eastern Europe (Gabrielová et al., 2011; Kaplan et al., 2015). We also analysed herbarium specimens from historical lowland populations since $19^{\text {th }}$ century. These data should help to suggest optimal conservation actions for the species. We ask the following questions: 
1) What is the genetic structure of mountain and lowland populations and what does it tell about possible origin of the lowland populations?

2) Can the differences in genetic diversity among populations be explained by their lowland/mountain location and population size?

3) How much genetic variability was lost due to extinction of some lowland populations and the decline in size of the remaining ones?

\section{Methods}

\section{Study species}

Tofieldia calyculata (L.) Wahlenb. $(2 n=30)$ is a small diploid perennial plant from family Tofieldiaceae. Each individual consists of rosettes with several ensiform leaves. The inflorescence is a raceme with about 40 yellow flowers (Štěpánková, 2010). The fruit is a capsule with several dozens of tiny $(0.048 \mathrm{mg})$ brown seeds. The species has mixed reproductive system with possibility of selfing (personal observation from natural populations, also see S1 in Supplementary Material) and clonality. The species is distributed mainly in mountains of central Europe. Alps and Western Carpathians are the centre of the distribution range of the species. Peripheral populations occur in lowlands of central Europe (Czech Republic, Poland, Austria) with some isolated localities in Pyrenees, Romania and north-eastern Europe (Gotland island and Baltic states). In lowlands, species has disappeared from most of its historical localities and it is highly endangered. It is classified as vulnerable in Poland and Ukraine, endangered in Lithuania, critically endangered in the Czech Republic and Croatia, and extinct in Latvia and Hungary (Gabrielová et al. 2011).

In the Czech Republic, the species used to be quite common in several regions in the past. However, it has disappeared from almost all localities due to drainage, land-use changes and ongoing succession (Kaplan et al., 2015). From more than 50 localities recorded since $19^{\text {th }}$ century, the species currently grows only on 5 of them (Kaplan et al. 2015). The size of the remaining ones has been strongly reduced and currently ranges from 1 to 400 individuals (unpublished data).

The species grows in calcareous fens (Caricion davallianae, Sphagno warnstorfii- Tomentypnion nitensis), wet meadows (Molinion caerulae), calcareous pine and spruce woods (e.g. Erico carnae-pinion), on wet slopes and rocks, and in several habitats in alpine and subalpine zone in the mountains (Štěpánková, 2010).

\section{Data collection}

We collected samples from 30 recent populations of T. calyculata (Table 1, Fig.1A) covering all parts of the distribution range of the species including 13 central (mountain) populations and 17 peripheral (lowland) populations. We collected leaves from at least 20 individuals in every population, if possible. Leaves were collected from individuals equally distributed across the population to avoid sampling 
clones. Leaves were dried and stored in silicagel. The population size was estimated by estimating the number of flowering individuals. We were unable to record the number of vegetative plants as these can be easily overlooked in dense vegetation.

We also obtained leaves from 135 individuals from herbarium specimens from 6 herbaria from the Czech Republic and Switzerland (PRC, PR, CB, HR, LIT, BERN, see Table 2 and Table S2 in Supplementary material) collected between 1864 and 2011 and originated mostly from populations from the Czech Republic, but also from Italy, Austria, France, Switzerland, Slovakia and Sweden (Gotland island). Herbaria samples were used in Structure, PcoA and AMOVA analysis (Fig 1, for detail see below). Only subset of herbaria samples (samples from the Czech Republic were also used to explore the loss of genetic diversity in populations of Tofieldia calyculata in the Czech Republic since the $19^{\text {th }}$ century.

Altogether, we analysed 577 individuals (442 field samples, 135 herbarium samples).

\section{Genetic analysis}

We used 19 previously developed microsatellite markers for the analysis (Vlasta et al., 2020). DNA was extracted from leaf samples using modified CTAB method (Lodhi et al., 1994) with all volumes downscaled 10x. DNA amplification was done in two multiplex reactions (previously described in Vlasta et al., 2020) containing 2.5 $\mu \mathrm{L}$ of QIAGEN Multiplex PCR Master Mix and $20 \mathrm{ng}$ of DNA dissolved in $0.5 \mu \mathrm{L}$ of distilled water. For multiplex mix I (MM I), the PCR contained $1.94 \mu \mathrm{L}$ of primer mix (10 $\mu \mathrm{M}$ each in initial volume) and $0.06 \mu \mathrm{L}$ of $\mathrm{H} 2 \mathrm{O}$, for MM II the PCR contained $1.875 \mu \mathrm{L}$ of primer mix ( $10 \mu \mathrm{M}$ each in initial volume) and $0.125 \mu \mathrm{L}$ of $\mathrm{H} 2 \mathrm{O}$. The following conditions of Thermocycler were used: an initial denaturation step at $95^{\circ} \mathrm{C}$ for $10 \mathrm{~min}$; followed by 35 cycles of denaturation $\left(95^{\circ} \mathrm{C}\right.$ for $\left.30 \mathrm{~s}\right)$, annealing $\left(60^{\circ} \mathrm{C}\right.$ for $\left.40 \mathrm{~s}\right)$, and extension $\left(72^{\circ} \mathrm{C}\right.$ for $\left.30 \mathrm{~s}\right)$; and a final extension at $72^{\circ} \mathrm{C}$ for $8 \mathrm{~min}$. PCR products were diluted with ddH2O 10x (PCR product of MMI) and 20x (PCR product of MMII). Each PCR product $(1 \mu \mathrm{L})$ was mixed with $12 \mu \mathrm{L}$ of formamide mixed with $0.1 \mu \mathrm{L}$ of size standard (GeneScan $500 \mathrm{LIZ}$; Thermo Fisher Scientific, Waltham, Massachusetts, USA). Fragment lengths were determined by capillary gel electrophoresis with an ABI 3130 Genetic Analyzer using GeneMapper 4.0 (Thermo Fisher Scientific).

For analysis of herbarium specimens, the Thermocycler conditions were modified by prolonging time for denaturation, annealing and extension steps: an initial denaturation step at $95^{\circ} \mathrm{C}$ for $10 \mathrm{~min}$; followed by 35 cycles of denaturation $\left(95^{\circ} \mathrm{C}\right.$ for $\left.90 \mathrm{~s}\right)$, annealing $\left(60^{\circ} \mathrm{C}\right.$ for $\left.120 \mathrm{~s}\right)$, and extension $\left(72^{\circ} \mathrm{C}\right.$ for $\left.120 \mathrm{~s}\right)$; and a final extension at $72^{\circ} \mathrm{C}$ for 8 min. PCR products were not diluted (for herbarium specimens from 18641939) or were diluted $5 \times$ (for herbarium specimens from 1940-2015).

\section{Data analysis}

We excluded 2 loci from further analyses due to high proportion of missing alleles. All analyses were thus done with 17 loci. We excluded individuals from herbarium specimens with less than $70 \%$ loci amplified (mainly from older herbarium specimens, 35 individuals) for further analyses. 
We divided populations into 2 groups - mountain populations (populations from Alps and Carpathians; species is common and it is not endangered, altitude ranging between 650 and $2040 \mathrm{~m}$ ) and lowland populations (from the Czech Republic, Poland, Estonia, Gotland island and lowlands of Austria; species is not common and it is endangered, altitude between 4 and $580 \mathrm{~m}$ ).

We used SPAGEDi (Hardy and Vekemans 2002) to calculate number of alleles, observed and expected heterozygosities, allelic richness, $F_{S T}$ and individual inbreeding coefficient $\left(F_{1}\right)$. Additionally, we calculated percentage of polymorphic loci, counted number of unique alleles for each population (alleles present in only one population) and for lowland and mountain populations (alleles found only in one of these two groups). GENEPOP version 4.2 (Rousset, 2008) was used to test deviation of each population from Hardy-Weinberg equilibrium. Individuals from herbarium specimens from the same locality collected in different years were analysed as one population if the time between years did not exceed 20 years. Populations with less than 5 individuals were excluded from these analyses.

We calculated pair-wise correlations among all the genetic characteristics using MS Excel. All except $F_{\text {I }}$ were highly correlated to each other (see table S3 in Supplementary Material). We thus only analysed $F_{1}$ and allelic richness as representatives of all the other variables and commonly used measures of genetic diversity in similar studies.

We tested the effect of distribution of population (lowland, mountain) and logarithm of population size on genetic characteristics of populations (allelic richness and $F_{1}$ ) using generalized linear model with Gamma distribution (in case of allelic richness) and ANOVA (in case of $F_{l}$ ) using R version 3.6.3 ( $R$ development team, 2017). Populations with less than 5 individuals were excluded from these analyses. We also excluded all populations from herbaria for this analysis - we compared only current populations.

\section{Genetic structure of the populations}

STRUCTURE analysis (Pritchard et al., 2000) was performed to reveal the structure of the populations. First, we removed all clones from the analysis using AFLPDAT function clone (Ehrich, 2006) in R version 3.6.3 (R development team, 2017). All the remaining samples were used including all samples for herbarium specimens with more than $70 \%$ loci amplified (altogether 408 individuals). We excluded historical herbarium samples that duplicated our recent data (herbarium specimens from the same populations from different time periods). The analysis was run with $\mathrm{K}$ from 1 to 10 with a burn-in period of 100,000 iterations and run for 1,000,000. Ten individual runs were performed for each $\mathrm{K}$. The admixture model was used. Optimal $\mathrm{K}$ was determined by Evanno method (Evanno et al., 2005) based on the $\Delta \mathrm{K}$ statistic using Structure Harvester (Earl and von Holdt, 2012).

We also performed PcoA analysis based on Jaccard coefficients using PAST version 2.17c (Hammer et al., 2001). To test distribution of genetic variability between lowland and mountain populations, between populations within the groups and within populations, we performed AMOVA using Arlequin (Excoffier 
and Lischer 2010). Three analyses were done - one including two geographic groups (lowland, mountain) and two separate analyses of each group.

Results from STRUCTURE showed presence of two genetic clusters (groups) with some mixed populations between them. These two groups were then analysed separately to reveal sub-structure of these 2 groups using both STRUCTURE and PcoA. Mixed populations (populations $<0.8$ probability of belonging to first or second cluster) were not included in these analyses. In the first group, 18 populations with 169 individuals were analysed, in the second group, 34 populations with 186 individuals were analysed.

\section{Analysis of herbarium samples}

We used generalized linear model with Gamma distribution to test the effects of herbarium specimen age and location at which it was stored on the amplification success using linearly transformed percentage of amplified loci as dependent variable. We were not able to test the interaction between the two variables as plants from different herbaria originated from different years. We used all the data from herbaria in this analysis. The analysis was done using $R$ version 3.6.3 (R development team, 2017)

We used only samples from the Czech Republic in the next analysis, both current samples and herbaria historical samples from 1864 to 1986. Samples were divided into six groups based on geographic distribution of the species (Table 2). In four regions (Džbán, Polabí, Českolipsko region and southern Bohemia), where current populations are present, we counted all alleles amplified for all loci in all samples (even in samples where less than $70 \%$ loci were amplified) for each region. We compared the alleles from the past with alleles in the current populations. We divided all alleles found in each of the four regions into three groups - 1) alleles present in current populations, 2) alleles which have disappeared from current populations (i.e. present in the historical, but not recent samples, genetic loss on within population level), 3) alleles which have disappeared from extinct populations (genetic loss on between population level) and estimated proportion of alleles in each of the groups.

\section{Results}

\section{Genetic diversity of lowland and mountain populations}

We found 158 alleles in the 17 scored loci. The percentage of polymorphic loci in a population ranged between 0 and $100 \%$. Allelic richness ranged between 1 and 2.09. Observed and expected heterozygosities ranged between 0 to 0.432 and 0 to 0.512 , respectively. The highest genetic diversity was found in mountain population Weißenbach in Eastern Alps. The lowest genetic diversity was found in two lowland populations Ojcowski park narodowy in Poland and Cikánský dolík in the Czech Republic. The highest number of unique alleles was found in population Weißenbach (7 unique alleles). Other unique alleles were found in other mountain populations and few unique alleles were found in lowland populations (see Fig. 2, Table 1 and 2). Fifty alleles (31.6\%) were found only in mountain populations, 12 alleles $(7.6 \%)$ were found only in lowland populations. 
Lowland populations had reduced allelic richness compared to mountain populations (Table 3, Fig.2 and 3). Individual inbreeding coefficient (FI) did not differ between lowland and mountain populations (Table 3 , Fig 3). Neither allelic richness, nor FI were influenced by population size (Table 3).

We found significant deviance from Hardy-Weinberg equilibrium in almost all populations (Genepop, $p<0.05$ ) except two mountain (Le Taillefer, Mount Rax) and two lowland populations (Bagno Serebryskie, Jestřebské slatě). Individual inbreeding coefficient was also highly significantly different from 0 in almost all populations, with exceptions of populations Bagno Serebryskie and Jestřebské slatě (Tables 1 and 2).

\section{Genetic structure of the populations and origin of lowland populations}

AMOVA analysis revealed that $7.25 \%$ of variability was between lowland and mountain populations, $54.2 \%$ of variability between populations within groups and $38.55 \%$ within populations. In separate analyses of each group, $44.7 \%$ of variability was between populations in mountains whereas $68.2 \%$ of the variability was between populations in lowlands (Table 4).

In Structure analysis, the most likely number of clusters was assigned to two groups based on the $\Delta \mathrm{K}$ statistic ( $K=2$, Table S4 in Supplementary Material, Fig 1A). First group consists of populations from eastern Alps, western Carpathians, Estonia and Gotland. Second group contained the remaining populations - populations from northern Bohemia, Poland, central, southern and western Alps and Pyrenes. Populations from lowlands of Austria and from southern Bohemia were mixed. These results were also supported by PcoA analysis (Fig.4). Lowland and mountain populations were not distinguished.

After separate STRUCTURE and PcoA analysis three sub-groups were found within the first group $(K=3$, Table S4, Fig 1B) - populations from Estonia and Gotland, Carpathian populations and populations from Eastern Alps (Fig. 1B and 4). Within the second group, two sub-groups were recognized after separate STRUCTURE analysis ( $K=2$, Table S4, Fig. 1B) - populations from central, southern and western Alps together with populations from southern Poland form one sub-group, populations from northern Bohemia and south-eastern Poland (Lublin region) form another group (Figures 1B and 4).

\section{Recent changes in genetic diversity in lowland populations from the Czech Republic}

Analysis of herbarium specimens from the Czech Republic showed that $43.4 \%$ of alleles observed in herbarium specimens was lost due to extinction of the species from almost all historical localities. Comparison of the four main regions where the species was present in the past shows that more genetic diversity was lost in some regions than in others (Fig.5). In Polabí region and southern Bohemia (where only few individuals are currently present) around half of the variability was lost (59\%, 49\% respectively). In Českolipsko region and Džbán region, where current populations with hundreds or dozens of individuals still exist, only $21 \%$ and $14 \%$ of variability was lost respectively. Almost all Czech historical populations had a low within population genetic diversity compared to central mountain populations and the populations were highly differentiated. Main part of the genetic variability was therefore lost due to 
extinction of whole populations. Percentage of amplified loci was significantly affected by age of the herbarium specimen (GLM, Explained deviance $=40.83, p<0.001$, Fig.6) and also by their storage place (GLM, Explained deviance $=36.06, p<0.001)$.

\section{Discussion}

\section{Genetic diversity of lowland and mountain populations}

We found significantly lower genetic diversity in lowland peripheral populations compared to mountain populations. Low genetic diversity (Vogler and Reisch, 2013; Duwe et al., 2017) and high genetic differentiation (Greimler and Dobeš, 2000; Vogler and Reisch, 2013; Duwe et al., 2017) were also found in other species with remnant lowland populations. Other studies showed almost no genetic diversity in lowland populations compared to the mountains (e.g. Machon et al., 2001; Kirschner et al. 2011). Our results indicate that despite of lowered genetic diversity of lowland populations, they still contain relatively high amount of genetic variability including some unique alleles and alleles which are not present in mountain populations. This is consistent with results of other studies on species with similar distribution (Reisch et al. 2002; Reisch et al. 2003; Duwe et al. 2018) reporting more genetic variability in mountains, but with enough genetic variability in lowlands.

We did not find any relationship between genetic diversity and population size. Positive relationship between population size and genetic diversity is well-supported in the literature (Tomimatsu andOhara 2003; Leimu et al. 2006; Šmídová et al. 2011; Dostálek et al. 2014; Münzbergová et al. 2018) . However, other studies showed no relationship (Pluess and Stöcklin 2004; Bachmann and Hensen 2007; Klank et al. 2012). While some lowland populations of $T$. calyculata with very low genetic diversity are very small, we also found no genetic diversity in a large viable (based on our unpublished demographic data) population in Ojcowski park narodowy, where all the plants sampled had the same genotype. We also found very low genetic diversity in one large mountain Carpathian population (Pusté Pole). Similarly, almost no genetic diversity was found in Estonian populations. Estonian populations are located on island of Saarema and their low genetic diversity could be consequence of postglacial colonization of this formerly glaciated area. The low genetic diversity in several large viable populations suggests that low genetic diversity may not be a problem for the species. Although there are many studies that showed the importance of genetic diversity for fitness of individuals and plant populations (e.g. Luijten et al., 2002; Picó et al., 2007; Ilves et al. 2013), there is evidence from other rare species which are able to survive and form viable populations even with low levels of genetic diversity (Lammi et al., 1999; Noel et al., 2007; Vogler and Reisch, 2013; Plenk et al., 2019). It is thus likely that loss of genetic diversity is not the key reason for the decline of the populations of $T$. calyculata. The small populations are likely small due to unsuitable habitat conditions and not low genetic diversity. Tofieldia calyculata is a long-lived perennial species, so it is possible that negative consequences of loss of genetic diversity will appear in the next generations (but see the chapter below about herbaria samples). We also did not study the effect of genetic diversity on fitness of the individuals. 
T. calyculata is self-compatible (field observations, also see $\mathrm{S} 1$ in Supplementary Material). This is in line with significant deviance from Hardy-Weinberg equilibrium in almost all populations and high $\mathrm{F}_{\text {. }}$. Selfing species are less affected by low genetic diversity than self-incompatible species ( Hamrick and Godt 1996; Honnay and Jacquemyn 2007; Segarra-Moragues and Mateu-Andrés 2007). F/ did not differ between lowland and mountain populations indicating selfing probably happens in all populations. Selfing of the species is also supported by results of AMOVA analysis which revealed higher proportion of variability between than within populations with the difference being larger in lowland populations. This indicates higher selfing and isolation of lowland populations possibly explaining their lower genetic diversity.

\section{Genetic structure of the populations and origin of lowland populations}

Results of STRUCTURE analysis did not confirm the clear separation of lowland and mountain populations and showed that the situation is more complex. Both lowland and mountain populations form several independent groups. Populations from north-eastern limestone Alps are more closely related to Carpathian populations than to the rest of the populations from Alps. Similar genetic split between populations from western and eastern Alps was described in range of previous studies (Ronikier et al. 2008; Thiel-Egenter et al. 2011; Ronikier et al. 2012; Slovák et al. 2012). While eastern Alps and western Carpathians were not glaciated or hosted only small glacial sheets, central and western Alps were covered by huge glacier (Ivy-ochs, 2015). Eastern Alps and western Carpathians are therefore proposed to be glacial refugia for many cold-adapted species ( Schönswetter et al. 2005; Ronikier et al. 2008; Slovák et al. 2012; Dítě et al. 2018). In line with this, the highest number of unique alleles and also the highest values of allelic richness and heterozygosities were found in populations on southern and north-eastern edges of Alps and also in some western Carpathian populations suggesting possible glacial refugia for $T$. calyculata. Suitable habitats including calcareous fens were probably present in non-glaciated parts of Alps and western Carpathians during the last ice-age (Janská et al., 2017). After tree expansion in Holocene, fen species such as T. calyculata likely survived on old fens originated in late glacial or at beginning of Holocene (Hájek et al., 2011; Hájková et al., 2020). Indeed, the highest genetic diversity within western Carpathians was found in population in Belianské lúky, biggest Slovak fen more than 10000 years old hosting many relict species (Hájková et al., 2012). Populations from Western Carpathians or Eastern Alps could be a source of postglacial colonization of northern areas (Estonia, Gotland) as shown by high similarity of these populations in our study. Role of Carpathians as source of postglacial colonization of Baltic area was recently also described in Arabidopsis arenosa (Kolář et al., 2016).

Presence of glacial refugia in lowlands is possible. Lowland populations have low within population but high between population genetic diversity. This pattern was previously assigned to relict populations (Reisch et al. 2003; Hensen et al. 2010). While in mountain populations $44.2 \%$ of variability was among populations, in lowland populations $68.2 \%$ of variation was among the populations indicating restricted gene flow among lowland populations. Populations of $T$. calyculata in lowlands could have existed already during the last glacial period and their low genetic diversity could be due to reduction of 
population sizes together with restricted gene flow leading to strong genetic drift after forest expansion during Holocene. Differentiation of populations was also supported by selfing of the species.

Possible lowland occurrences of $T$. calyculata during last ice-age are also supported by palynological records. Pollen of Tofieldia sp. was found in late Glacial or at beginning of Holocene in central Bohemia (Pokorný et al., 2015), in Estonia (Niinemets et al. 2002) and in lowlands of Germany (Brande, 1996) and Poland (Ralska-Jasiewiczowa and Rzętkowska 1987). Pollen of T. calyculata cannot be distinguished from pollen of Tofieldia pusilla which currently co-occurs with T. calyculata in Alps and Tatra Mountains, but the distribution of the species does not overlap in lowlands nowadays. It however cannot be excluded that pollen found in the palynological records was pollen of T. pusilla.

Relict character of the lowland populations is further supported by presence of unique alleles in some lowland populations. Unique alleles were found in lowland populations in the Czech Republic, Poland, Estonia and in populations from lowlands of Austria. In the Czech Republic, we found some unique alleles in two historical populations (Polabská černava, Cibulka). In the region of Polabská černava (Polabí region), the species grew in old fen localities whose history goes back to late Glacial period (Petr and Novák 2014). The species co-occurred with other fen species considered as relicts such as Cladium mariscus (Pokorny et al. 2010) or Ligularia sibirica (Hendrych 2003; Šmídová et al. 2011).

Alternative hypothesis of origin of lowland populations of T. calyculata can be postglacial colonisation from glacial refugia as previously described in Primula farinosa (Theodoridis et al., 2017), the species with quite similar distribution and ecology or in Polygala chamaebuxus (Windmaißer et al., 2016). This hypothesis does not contradict the arguments mentioned above. In this scenario, lowland populations could be considered as post-glacial relicts with sufficiently long history to allow occurrence of some new genetic variability. This hypothesis cannot be excluded especially due to lower genetic diversity of lowland populations. The postglacial expansion is probable especially in populations from north-eastern Europe (Estonia, Gotland). To conclude, lowland populations are probably result of both processes postglacial colonisation from glacial refugia and interglacial contraction of relict lowland populations.

\section{Recent changes in genetic diversity in lowland populations from the Czech Republic}

There are still some methodological problems when performing genetic analysis of herbarium samples, such as different sampling of plants, missing data, mistakes in labels and lower quality of DNA due to high age of specimens and conditions of their storage (recently reviewed by Bieker and Martin, 2018). We found that percentage of amplified loci was significantly affected by the age of the herbarium specimens with lower amplification in older samples, although some old herbarium specimens from $19^{\text {th }}$ century were successfully amplified. Using herbarium samples for testing loss of genetic diversity in rare species is still not common (but see Cozzolino et al. 2007; Beatty et al., 2014; Frey et al., 2017). Cozzolino et al. (2007) documented loss of genetic diversity and increased differentiation of populations of Anacamptis palustris after human-mediated landscape changes. Shifts in genetic diversity was also documented using herbarium specimens of Trapa natans (Frey et al., 2017) and Saxifraga hirculus (Beatty et al. 
2014). In T. calyculata, historical populations had very low genetic diversity, even when corrected for the different sample size of current and historical populations (allelic richness values). Comparison of pool of alleles from herbarium specimens with pool of alleles from present populations suggests that $43.4 \%$ of alleles observed in herbarium specimens was lost and the loss was mostly due to extinction of whole populations (Fig.5). The loss was larger in Polabí and southern Bohemia regions with only few remaining plants present at the moment (59 and $49 \%$ of variability lost). In contrast, in regions still hosting remaining populations (Českolipsko, Džbán) only 21 and $14 \%$ of the variation has been lost. In the largest Czech population - Jestřebské slatě (Českolipsko region), the same alleles were present in 1930s, 1980s and nowadays. Some other alleles were found in this population in 1910s, but low percentage of amplified loci disable us to make conclusions about the genetic diversity before 1930s. In the second biggest population, Cikánský dolík (Džbán region), all plants have the same genotype at the moment. We found few other alleles in herbarium specimens from $19^{\text {th }}$ century in this population, but within population genetic diversity was negligible already in the $19^{\text {th }}$ century. The changes in genetic diversity could have happen before the $20^{\text {th }}$ century. The low number of samples from $19^{\text {th }}$ century and the bad quality of their DNA do not allow us to assess the full diversity of the populations in this period. In addition, no herbarium samples before 1860 s are available.

\section{Conservation recommendations}

Lowland populations are genetically different from mountain populations although the differentiation is more complicated. They contain some unique alleles and alleles which were not found in mountain populations. We found that a lot of diversity was found between populations, indicating large differentiation of populations of $T$. calyculata. Every population of T. calyculata is in a way unique and deserves protection and multiple populations have to be protected to save maximum of genetic diversity.

Existence of large viable populations with very low genetic diversity suggests that populations of $T$. calyculata can be restored even from last individuals remaining. Almost no genetic variability was lost on within population level at least during the time period disponible from herbarium specimens. All this suggest that the recent declines of the populations are not due to loss of genetic diversity.

Mountain populations from Alps and Carpathians are not currently endangered. They can be however endangered by future climate change due to habitat shifts and change of environmental conditions (Dirnböck et al. 2003). Mountain populations containing high portion of genetic diversity thus should not be neglected neither when setting conservation priorities to protect this species.

\section{Declarations}

\section{Acknowledgments}

We thank to herbaria curators of museums (PRC, PR, CB, HR, LIT, BERN) for providing samples from historical localities in the Czech Republic and samples from Alps. We would like to thank to Toomas Kukk for collecting samples from Estonia and to F. Kolář, C. Pachschwöll, T. Pachschwöll and Katja Rembold 
for collecting samples from Alps. We would also like to thank to many people and organisations involved in getting permission and helping with finding suitable populations for research (namely Norbert Pühringer and Kristina Plenk).

We also thank Gabriela Šrámková for help with data analysis, to Andrea Jarošová and Maria Šurinová for consulting methodology of analysis of herbarium samples and to Vojtěch Abraham, Anna Šolcová and many other people and anonymous reviewers for comments for improving manuscript.

Funding: This work was supported by the Charles University Grant Agency (grant no. 1450218)

Conflicts of interests: The authors have no financial or proprietary conflicts of interests

We obtained all permission to enter to protected areas and for manipulation with the species in countries where the species is protected.

\section{References}

Bachmann U, Hensen I (2007) Is declining Campanula glomerata threatened by genetic factors? Plant Spec Biol 22: 1-10

Beatty GE, Reid N, Provan J (2014) Retrospective genetic monitoring of the threatened Yellow marsh saxifrage (Saxifraga hirculus) reveals genetic erosion but provides valuable insights for conservation strategies. Divers Distrib 20: 529-537

Bieker VC, Martin MD (2018) Implications and future prospects for evolutionary analyses of DNA in historical herbarium collections. Botany Letters 165: 409-418

Brande A (1996) Pollen profile Tegeler See, Brandenburg, Germany. In Supplement to: Brande, A (1996): Type region D-s, Berlin. In: Berglund, BE; Birks, HJB; Ralska-Jasiewiczowa, M; Wright, HE (eds.) Palaeoecological events during the last 15000 years:regional syntheses of palaeoecological studies of lakes and mires in Euro. PANGAEA.

Cozzolino S, Cafasso D, Pellegrino G, Musacchio A, Widmer A (2007) Genetic variation in time and space: The use of herbarium specimens to reconstruct patterns of genetic variation in the endangered orchid Anacamptis palustris. Conserv Genet 8: 629-639

Dirnböck T, Dullinger S, Grabherr G (2003) A Regional Impact Assessment of Climate and Land-Use Change on Alpine Vegetation. J Biogeogr 30: 401-417

Dítě D, Hájek M, Svitková I, Košuthová A, Šoltés R, Kliment J (2018) Glacial-relict symptoms in the Western Carpathian flora. Folia Geobot 53: 277-300

Dostálek T, Münzbergová Z, Plačková I (2014) High genetic diversity in isolated populations of Thesium ebracteatum at the edge of its distribution range. Conserv Genet 15: 75-86 
Duwe V, Muller L, Borsch T, Ismail S (2017) Pervasive genetic differentiation among Central European populations of the threatened Arnica montana L. and genetic erosion at lower elevations. Perspect Plant Ecol, Evolution and Systematics 27: 45-56

Duwe V, Muller L, Reichel K, Zippel E, Borsch T, Ismail S (2018) Genetic structure and genetic diversity of the endangered grassland plant Crepis mollis (Jacq.) Asch. as a basis for conservation management in Germany. Conserv Genet 19: 527-543

Earl DA, von Holdt BM (2012) STRUCTURE HARVESTER: A website and program for visualizing STRUCTURE output and implementing the Evanno method. Conserv Genet Resour 4: 359-361

Eckert CG, Samis KE, Lougheed SC (2008) Genetic variation across species' geographical ranges: The central-marginal hypothesis and beyond. Mol Ecol 17: 1170-1188

Ehrich D (2006) AFLPDAT: A collection of R functions for convenient handling of AFLP data. Mol Ecol Notes 6: 603-604

Excoffier L, Lischer HEL (2010) Arlequin suite ver 3.5: A new series of programs to perform population genetics analyses under Linux and Windows. Mol Ecol Resour 10: 564-567

Frankham R, Ballou J, Briscoe D (2010) - Introduction to Conservation Genetics (2nd ed.). Cambridge University Press

Frey D, Reisch C, Narduzzi-Wicht B, Baur EM, Cornejo C, Alessi M, Schoenenberger N (2017) Historical museum specimens reveal the loss of genetic and morphological diversity due to local extinctions in the endangered water chestnut Trapa natans L. (Lythraceae) from the southern Alpine lake area. Bot $\mathrm{J}$ Linn Soc 185: 343-358

Gabrielová J, Fialová T, Münzbergová Z (2011) Critically endangered plant species of the Czech Republic: What is the situation of their endangerment in other European countries? Príroda 31: 299- 343

Gibson SY, van Der Marel RC, Starzomski BM (2009) Climate change and conservation of leading-edge peripheral populations. Conserv Biol 23: 1369-1373

Greimler J, Dobeš C (2000) High genetic diversity and differentiation in relict lowland populations of Gentianella austriaca (A. and J. Kern.) Holub (Gentianaceae). Plant Biol 2: 628-637

Hájek M, Horsák M, Tichý L, Hájková P, Dítě D, Jamrichová E (2011) Testing a relict distributional pattern of fen plant and terrestrial snail species at the Holocene scale: a null model approach. J Biogeogr 38: $742-755$

Hájková P, Grootjans A, Lamentowicz M, Rybníčková E, Madaras M, Opravilová V, Michaelis D, Hájek M, Joosten H, Wolejko L (2012) How a Sphagnum fuscum-dominated bog changed into a calcareous fen: The unique Holocene history of a Slovak spring-fed mire. J Quaternary Sci 27: 233-243 
Hájková P, Jamrichová E, Šolcová A, Frodlová J, Petr L, Dítě D, Hájek M, Horsák M (2020) Can relict-rich communities be of an anthropogenic origin? Palaeoecological insight into conservation strategy for endangered Carpathian travertine fens. Quaternary Sci Rev 234: 1-13

Hampe A, Petit RJ (2005) Conserving biodiversity under climate change: The rear edge matters. Ecol Lett 8: $461-467$

Hamrick JL, Godt MJW (1996) Effects of life history traits on genetic diversity in plant species. Philos T R Soc B 351: 1291-1298

Hardie DC, Hutchings JA (2010) Evolutionary ecology at the extremes of species' ranges. Environ Rev 18: $1-20$

Hardy OJ, Vekemans X (2002) SPAGeDi: a versatile computer program to analyse spatial genetic structure at the individual or population levels. Mol Ecol Notes 2: 618-620

Hendrych R (2003) Poznatky o druhu Ligularia sibirica v Čechách. Preslia 75: 39-69

Hensen I, Kilian C, Wagner V, Durka W, Pusch J, Wesche K (2010) Low genetic variability and strong differentiation among isolated populations of the rare steppe grass Stipa capillata L. in Central Europe. Plant Biol 12: 526-536

Honnay O, Jacquemyn H (2007) Susceptibility of Common and Rare Plant Species to the Genetic Consequences of Habitat Fragmentation. Conserv Biol 21: 823-831

Hunter M L, Hutchinson A (1994) The virtues and shortcomings of parochialism: Conserving species that are locally rare, but globally common. Conserv Biol 8: 1163-1165

Ivy-ochs S (2015) Glacier variations in the european Alps at the end of the last glaciation. Cuaderm Investig 41: 295-315

Janská V, Jimenéz-Alfaro B, Chytrý M., Divíšek J, Anenkhonov O, Korolyuk A, Lashchinskyi N, Culek M (2017) Palaeodistribution modelling of European vegetation types at the Last Glacial Maximum using modern analogues from Siberia: Prospects and limitations. Quaternary Sci Rev 159: 103-115

Kaplan Z, Danihelka J, Štěpánková J, Bureš P, Zázvorka J, Hroudová Z, Ducháček M, Grulich V, Řepka R, Dančák M, Prančl J, Šumberová K, Wild J, Trávníček B (2015) Distributions of vascular plants in the Czech Republic. Part 1. Preslia 87: 417-500

Kirschner J, Kirschnerová L, Bartish I (2011) Conservation status of two isolated populations of Gentiana verna (Gentianaceae) in the Czech Republic: Insights from an allozyme analysis. PHYTON-Ann Rei Bot A 51: 177-199 
Klank C, Ghazoul J, Pluess AR (2012) Genetic variation and plant performance in fragmented populations of globeflowers (Trollius europaeus) within agricultural landscapes. Conserv Genet 13: 873-884

Knotek A, Kolář F (2018) Different low-competition island habitats in Central Europe harbour similar levels of genetic diversity in relict populations of Galium pusillum agg. (Rubiaceae). Biol J Linn Soc 125: 491507

Kolář F, Fuxová G, Záveská E, Nagano AJ, Hyklová L, Lučanová M, Kudoh H, Marhold K (2016) Northern glacial refugia and altitudinal niche divergence shape genome-wide differentiation in the emerging plant model Arabidopsis arenosa. Mol Ecol 25: 3929-3949

Kropf M, Bardy K, Höhn M and Plenk K (2020) Phylogeographical structure and genetic diversity of Adonis vernalis L. (Ranunculaceae) across and beyond the Pannonian region. Flora 262: 151497

Lammi A, Siikamäki P and Mustajärvi K (1999). Genetic Diversity, Population Size, and Fitness in Central and Peripheral Populations of a Rare Plant Lychnis viscaria. Conserv Biol 13: 1069-1078

Leimu R, Mutikainen P, Koricheva J, Fischer M (2006) How general are positive relationships between plant population size, fitness and genetic variation? J Ecol 94: 942-952

Lodhi MA, Ye G, Weeden NF, Reisch BI (1994) A Simple and Efficient Method for DNA Extraction from Grapevine Cultivars and Vitis species. Mol biol rep 12: 6-13

Lutz E, Schneller JJ, Holderegger R (2000) Understanding population history for conservation purposes: Population genetics of Saxifraga aizoides (Saxifragaceae) in the lowlands and lower mountains north of the Alps. Am J Bot 87: 583-590

Machon N, Guillon JM, Dobigny G, Le Cadre S, Moret J (2001) Genetic variation in the horsetail Equisetum variegatum Schleich., an endangered species in the Parisian region. Biodivers Conserv 10: $1543-1554$

Mráz P, Gaudeul M, Rioux D, Gielly L, Choler P, Taberlet P (2007) Genetic structure of Hypochaeris uniflora (Asteraceae) suggests vicariance in the Carpathians and rapid post-glacial colonization of the Alps from an eastern Alpine refugium. J Biogeogr 34: 2100-2114

Münzbergová Z, Šurinová M, Husáková I, Brabec J (2018) Strong fluctuations in aboveground population size do not limit genetic diversity in populations of an endangered biennial species. Oecologia 187: 863872

Niinemets E, Saarse L, Poska A (2002) Vegetation history and human impact in the Parika area, Central Estonia. P Est Acad Sci 51: 241-258

Noel F, Machon N, Porcher E (2007) No genetic diversity at molecular markers and strong phenotypic plasticity in populations of Ranunculus nodiflorus, an endangered plant species in France. Ann Bot- 
Petr L, Novák J (2014) High vegetation and environmental diversity during the Late Glacial and Early Holocene on the example of lowlands in the Czech Republic. Biologia 69: 847-862

Plenk K, Bardy K, Höhn M, Kropf M (2019) Long-term survival and successful conservation? Low genetic diversity but no evidence for reduced reproductive success at the north-westernmost range edge of $P o a$ badensis (Poaceae) in Central Europe. Biodivers Conserv 28: 1245-1265

Plenk K, Bardy K, Höhn M, Thiv M, Kropf M (2017) No obvious genetic erosion, but evident relict status at the westernmost range edge of the Pontic-Pannonian steppe plant Linum flavum L.(Linaceae ) in Central Europe. Ecol Evol 7: 6527-6539

Pluess AR, Stöcklin J (2004) Genetic diversity and fitness in Scabiosa columbaria in the Swiss Jura in relation to population size. Conserv Genet 5: 145-156

Pokorný P, Chytrý M, Juřičková L, Sádlo J, Novák J, Ložek V (2015) Mid-Holocene bottleneck for central European dry grasslands: Did steppe survive the forest optimum in northern Bohemia, Czech Republic? Holocene 25: 716-726

Pokorny P, Sádlo J, Bernardová A (2010) Holocene history of Cladium mariscus (L.) pohl in the Czech republic. Implications for species population dynamics and palaeoecology. Acta Palaeobotanica 50: 6576

Pritchard J, Stephens M, Donnelly P (2000) Inference of Population Structure Using Multilocus Genotype Data. Genetics 155: 945-959

R development team (2017) R: A Language and Environment for Statistical Computing. R Foundation for Statistical Computing. URL: https://www.r-project.org

Ralska-Jasiewiczowa M, Rzętkowska A (1987) Pollen and macrofossil stratigraphy of fossil lake sediments at Niechorze I, W. Baltic coast. Acta Paleobotanica 27: 153-178

Reisch C, Poschlod P, Wingender R (2002) Genetic variation of Sesleria albicans Kit. ex Schultes (Poaceae): Lack of evidence for glacial relict endemism in central Europe. Plant Biol 4: 711-719

Reisch C, Poschlod P, Wingender R (2003) Genetic variation of Saxifraga paniculata Mill. (Saxifragaceae): Molecular evidence for glacial relict endemism in central Europe. Biol J Linn Soc 80: 11-21

Reisch C, Schmid C, Hartig F (2018) A comparison of methods for estimating plant population size. Biodivers Conserv 27: 2021-2028

Ronikier M, Cieślak E, Korbecka G (2008) High genetic differentiation in the alpine plant Campanula alpina Jacq. (Campanulaceae): Evidence for glacial survival in several Carpathian regions and long-term 
isolation between the Carpathians and the Alps. Mol Ecol 17: 1763-1775

Ronikier M, Schneeweiss GM, Schőnswetter P (2012) The extreme disjunction between Beringia and Europe in Ranunculus glacialis s. I. (Ranunculaceae) does not coincide with the deepest genetic split - a story of the importance of temperate mountain ranges in arctic - alpine phylogeography. Mol Ecol 21: $5561-5578$

Rousset F (2008) GENEPOP'007: A complete re-implementation of the GENEPOP software for Windows and Linux. Mol Ecol Resour 8: 103-106

Schönswetter P, Stehlík I, Holderegger R, Tribsch A (2005) Molecular evidence for glacial refugia of mountain plants in the European Alps. Mol Ecol 14: 3547-3555

Segarra-Moragues JG, Mateu-Andrés I (2007) Levels of allozyme diversity in closely related toadflaxes (Linaria, Plantaginaceae) and their correspondence with the breeding systems of the species. Conserv Genet 8: 373-383

Slovák M, Kučera J, Turis P, Zozomová-Lihová J (2012) Multiple glacial refugia and postglacial colonization routes inferred for a woodland geophyte, Cyclamen purpurascens: Patterns concordant with the Pleistocene history of broadleaved and coniferous tree species. Biol J Linn Soc 105: 741-760

Šmídová A, Münzbergová Z, Plačková I (2011) Genetic diversity of a relict plant species, Ligularia sibirica (L.) Cass. (Asteraceae). Flora 20: 151-157

Štěpánková J. (ed). (2010) Květena České republiky 8. Academia, Praha.

Theodoridis S, Randin C, Szovenyi P, Boucher FC, Patsiou TS, Conti E (2017) How do cold-adapted plants respond to climatic cycles? Interglacial expansion explains current distribution and genomic diversity in Primula farinosa L. Syst Biol 66: 715-736

Thiel-Egenter C, Alvarez N, Holderegger R, Tribsch A, Englisch T, Wohlgemuth T, Colli L, Gaudeul M, Gielly L, Linder HP, Negrin R, Niklfeld H, Pellecchia M, Schönswetter P, Taberlet P, Loo M, Winkler M, Gugerli F (2011). Break zones in the distributions of alleles and species in alpine plants. J Biogeogr 38: 772-782

Tomimatsu H, Ohara M (2003) Genetic diversity and local population structure of fragmented populations of Trillium camschatcense (Trilliaceae). Biol Conserv 109: 249-258

Vlasta T, Jarošová A, Šurinová M, Münzbergová Z (2020) Development of microsatellite markers for the perennial plant Tofieldia calyculata. Appl Plant Sci 8: 1-5

Vogler F, Reisch C, (2013) Vital survivors: Low genetic variation but high germination in glacial relict populations of the typical rock plant Draba aizoides. Biodivers Conserv 22: 1301-1316 
Wagner V, Durka W, Hensen I (2011) Increased genetic differentiation but no reduced genetic diversity in peripheral vs. central populations of a steppe grass Am J Bot 98: 1173-1179

Windmaißer T, Kattari S, Heubl G, Reisch C (2016) Glacial refugia and postglacial expansion of the alpine-prealpine plant species Polygala chamaebuxus. Ecol Evol 6: 7809-7819

Wroblewska A (2008) From the center to the margins of geographical range: molecular history of steppe plant Iris aphylla L. in Europe. Plant Syst and Evol 272: 49-65

\section{Tables}

Table 1. - List of current populations (from fresh material) used in the study - population genetic statistics included 


\begin{tabular}{|c|c|c|c|c|c|c|c|c|c|c|c|}
\hline Population & Country & Distribution & $\mathbf{N}$ & Ho & $\mathrm{He}$ & A & $\operatorname{Ar}(k=4)$ & $\mathbf{P}$ & $\begin{array}{l}\text { Unique } \\
\text { alleles }\end{array}$ & $\begin{array}{r}\text { Estimated } \\
\text { population size }\end{array}$ & FI \\
\hline Gosausee & $A U$ & $\mathrm{M}$ & 20 & 0.35 & 0.42 & 54 & 1.86 & 1 & 0 & 3000 & $0.18 *$ \\
\hline Dachstein & $\mathrm{AU}$ & M & 20 & 0.17 & 0.46 & 57 & 1.94 & 1 & 1 & 1500 & $0.62 *$ \\
\hline Weißenbach & $\mathrm{AU}$ & $\mathrm{M}$ & 20 & 0.41 & 0.51 & 75 & 2.09 & 0.94 & 7 & 350 & $0.20 *$ \\
\hline Innsbruck & $\mathrm{AU}$ & $\mathrm{M}$ & 5 & 0.15 & 0.34 & 36 & 1.68 & 0.82 & 1 & 150 & $0.58 *$ \\
\hline Mount Rax & AU & M & 9 & 0.43 & 0.51 & 51 & 2.07 & 0.94 & 2 & - & $0.15^{*}$ \\
\hline Le Taillefer & FR & M & 5 & 0.04 & 0.10 & 20 & 1.16 & 0.18 & 1 & - & $0.66^{*}$ \\
\hline Rotmoss+ & SWI & $\mathrm{M}$ & 3 & - & - & 23 & - & 0.38 & 2 & - & - \\
\hline Romoss+ & SWI & M & 3 & - & - & 23 & - & 0.35 & 0 & - & - \\
\hline Monkova dolina & SK & M & 20 & 0.17 & 0.37 & 47 & 1.75 & 0.88 & 1 & 150 & $0.56 *$ \\
\hline Belianské lúky & SK & M & 20 & 0.35 & 0.42 & 48 & 1.85 & 0.82 & 2 & 750 & $0.18 *$ \\
\hline Kláštorská roklina & SK & M & 13 & 0.01 & 0.19 & 28 & 1.35 & 0.53 & 0 & 75 & $0.93 *$ \\
\hline Pusté pole & SK & M & 20 & 0.11 & 0.16 & 28 & 1.31 & 0.47 & 0 & 1500 & $0.35 *$ \\
\hline Kanon Stratená & SK & M & 10 & 0.10 & 0.25 & 31 & 1.48 & 0.53 & 0 & 25 & $0.61 *$ \\
\hline Ibmermoor & AUS & $\mathrm{L}$ & 20 & 0.30 & 0.46 & 52 & 1.85 & 0.88 & 0 & 350 & $0.26 *$ \\
\hline Grabensee & AUS & $\mathrm{L}$ & 20 & 0.16 & 0.32 & 43 & 1.65 & 0.76 & 4 & 350 & $0.52 *$ \\
\hline Mautern & AUS & $\mathrm{L}$ & 15 & 0.004 & 0.05 & 21 & 1.1 & 0.18 & 0 & 7 & $0.93 *$ \\
\hline Młaki nad Pogorią & PL & $\mathrm{L}$ & 20 & 0.23 & 0.28 & 35 & 1.55 & 0.71 & 0 & 150 & $0.18^{*}$ \\
\hline Sosnowiec-bory & PL & $\mathrm{L}$ & 20 & 0.18 & 0.31 & 33 & 1.59 & 0.71 & 0 & 75 & $0.44^{*}$ \\
\hline Jaworzno-Szczakowa & PL & $\mathrm{L}$ & 20 & 0.11 & 0.32 & 35 & 1.61 & 0.71 & 1 & 350 & $0.66^{*}$ \\
\hline Ojcowski park narodowy & PL & $\mathrm{L}$ & 16 & 0 & 0 & 17 & 1 & 0 & 0 & 1500 & $1 *$ \\
\hline Bagno serebryskie & PL & $\mathrm{L}$ & 20 & 0.15 & 0.18 & 32 & 1.33 & 0.59 & 0 & 170 & 0.13 \\
\hline Brzezno & PL & $\mathrm{L}$ & 20 & 0.09 & 0.20 & 32 & 1.37 & 0.71 & 0 & 140 & $0.56^{*}$ \\
\hline Kihelkonna & EST & $\mathrm{L}$ & 15 & 0 & 0.008 & 18 & 1.01 & 0.06 & 0 & 350 & $1 *$ \\
\hline Paatsa & EST & $\mathrm{L}$ & 17 & 0.003 & 0.004 & 18 & 1.01 & 0.06 & 0 & 350 & 0 \\
\hline Viidumäe & EST & $\mathrm{L}$ & 19 & 0.06 & 0.14 & 30 & 1.27 & 0.41 & 1 & 150 & $0.60 *$ \\
\hline \multicolumn{12}{|l|}{ Jestřebské slate - Baronský } \\
\hline rybník & $\mathrm{CZ}$ & $\mathrm{L}$ & 23 & 0.12 & 0.14 & 23 & 1.24 & 0.29 & 0 & 100 & 0.14 \\
\hline V Bahnách & $\mathrm{CZ}$ & $\mathrm{L}$ & 3 & - & - & 17 & - & 0 & 0 & 1 & - \\
\hline Cikánský dolík & $\mathrm{CZ}$ & $\mathrm{L}$ & 21 & 0 & 0 & 17 & 1 & 0 & 0 & 25 & - \\
\hline Loučeň & $\mathrm{CZ}$ & $\mathrm{L}$ & 1 & - & - & 17 & - & 0 & 0 & 1 & - \\
\hline Kralovické louky & CZ & $\mathrm{L}$ & 4 & - & - & 17 & - & 0.06 & 0 & 4 & - \\
\hline
\end{tabular}

Notes: +from Bern botanical garden, $\mathrm{AU}=$ Austria, FR=France, SWI=Switzerland, SK=Slovakia, $\mathrm{PL}=$ Poland, $\mathrm{EST}=$ Estonia, $\mathrm{CZ}=$ the Czech Republic, $\mathrm{M}=$ mountain populations, L=lowland populations, $\mathrm{N}=$ number of samples analysed, Ho=observed heterozygosity, He=expected heterozygosity, $\mathrm{A}=$ number of alleles in population, $\mathrm{Ar}=$ allelic richness, $\mathrm{k}=$ number of gene copies, $\mathrm{P}=\%$ of polymorphic loci, $\mathrm{FI}=$ individual inbreeding coefficient, $\mathrm{m} * \mathrm{p}<0.05$ 
Table 2 - list of populations from herbaria used in this study, (populations and samples with unsuccessful amplification and herbaria accession numbers not included in the table - see table S2 in Supplementary Material) 


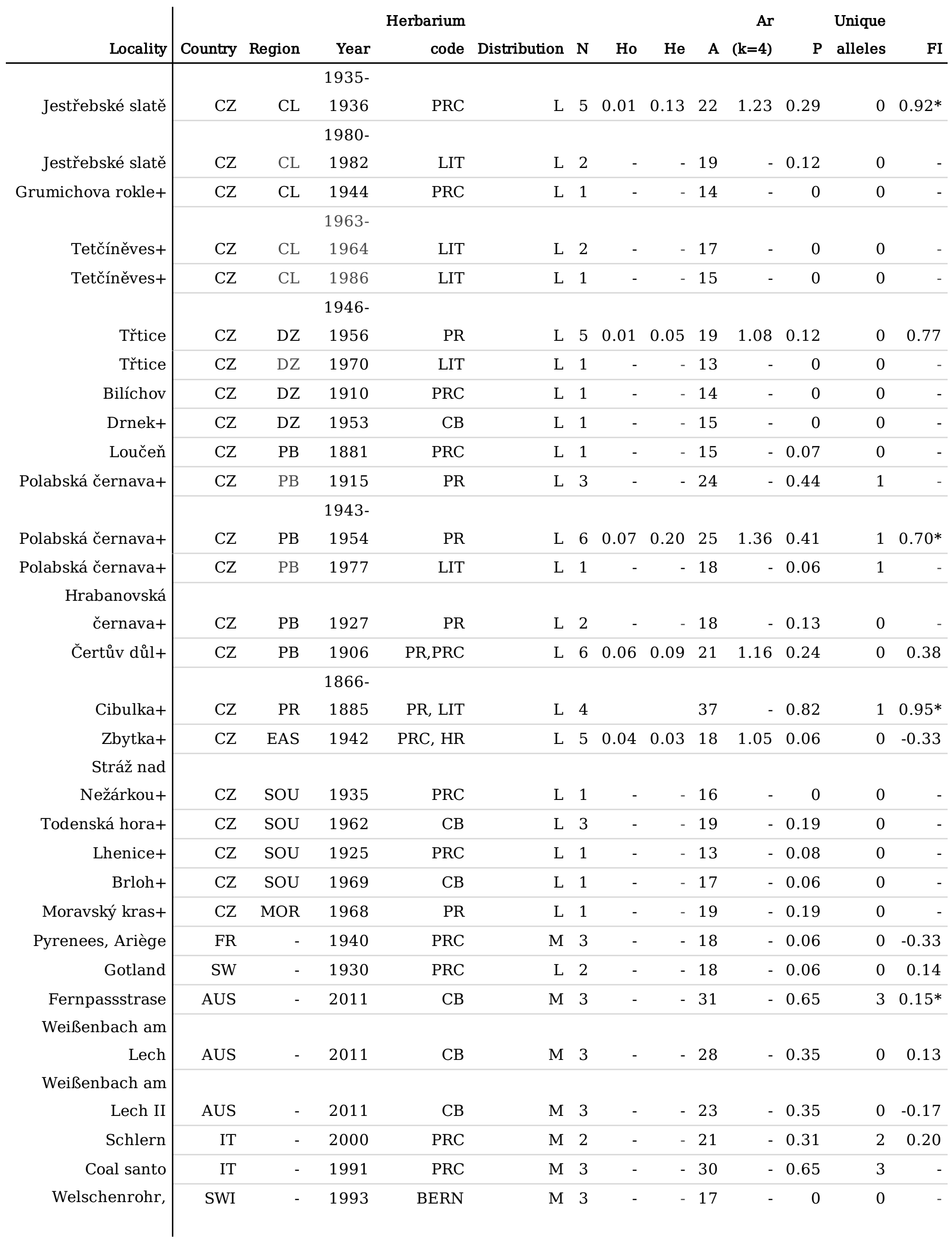




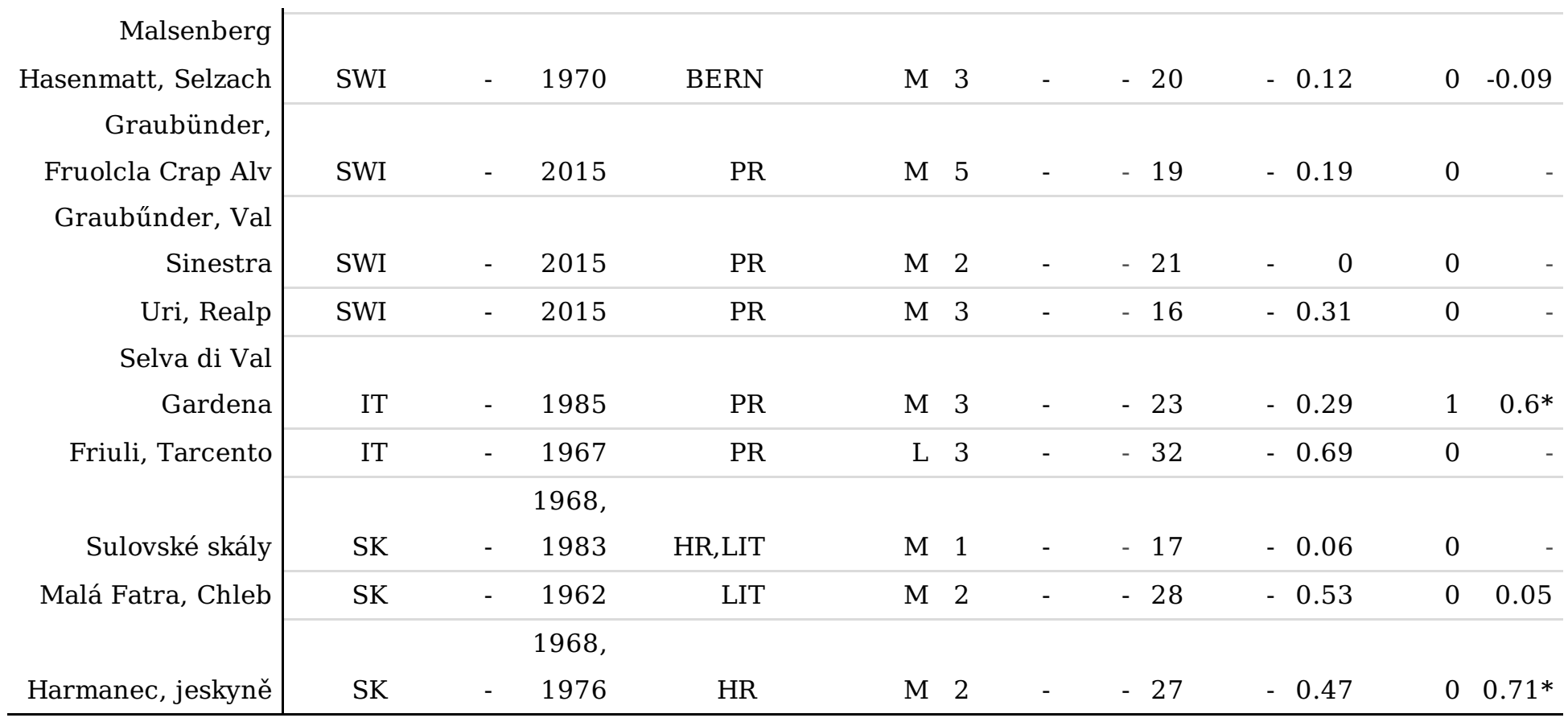

Notes: +extinct population, $\mathrm{CZ}=$ Czech Republic, $\mathrm{FR}=$ France, SW=Sweden, SWISwitzerland, AUS=Austria, $\mathrm{CL}=$ Českolipsko, $\mathrm{DZ}=\mathrm{Džbán}, \mathrm{PB}=$ Polabí, PR=Prague, EAS=Eastern Bohemia, SOU = Southern Bohemia, MOR=Moravia, L=Lowland populations, $\mathrm{M}=$ Mountain populations, $\mathrm{N}=$ number of samples, $\mathrm{Ho}=$ Observed heterozygosity, $\mathrm{H}=$ expected heterozygosity, $\mathrm{A}=$ number of alleles in population, $\mathrm{Ar}=$ allelic richness, $\mathrm{P}=$ percentage of polymorphic loci, $\mathrm{FI}=$ individual inbreeding coefficient, $* \mathrm{p}<0.05$

Table 3 - Relationship between allelic richness (Ar) and individuals inbreeding coefficient (FI) and distribution (lowland/mountain) and population size, GLM with gamma distribution was used in case of Allelic richness and ANOVA was used in case of FI

\begin{tabular}{|c|c|c|c|c|c|c|}
\hline & \multicolumn{3}{|l|}{$\mathrm{Ar}$} & \multicolumn{3}{|l|}{ FI } \\
\hline & Df & Explained deviance & p-value & Df & $\mathbf{F}$ & p-value \\
\hline Distribution & 1 & 0.27 & $0.007^{*}$ & 1 & 0.04 & 0.95 \\
\hline Log(Population size) & 1 & 0.09 & 0.13 & 1 & 1.74 & 0.20 \\
\hline Residuals & 20 & & & 20 & & \\
\hline
\end{tabular}

* significant value

Table 4 - Results from Analysis of molecular variance (AMOVA) - populations divided into lowland and mountain group (A) and separate analysis of each group (B,C) 


\begin{tabular}{l|rrr} 
& & & \\
Source of variation & Sum of squares & Variance components & Percentage variation \\
\hline A) Lowland and mountain group & & & 7.25 \\
Among groups & 269.85 & 0.38 & 54.2 \\
Among populations within groups & 2649.37 & 2.84 & 38.55 \\
\cline { 2 - 3 } Within populations & 1869.39 & 2.02 & \\
Total & 4786.62 & 5.25 & 31.83 \\
\hline & & & \\
B) Lowland populations & 1771.22 & 3.17 & 1.48 \\
Among populations & 832.64 & 4.65 & \\
Within populations & 2603.86 & & 44.71 \\
Total & & 2.32 & 55.29 \\
\hline & & 2.86 & \\
C) Mountain populations & 1034.76 & 5.18 & \\
Among populations & 1912.91 & & \\
Within populations & & & \\
Total & & & \\
\hline
\end{tabular}

Figures 

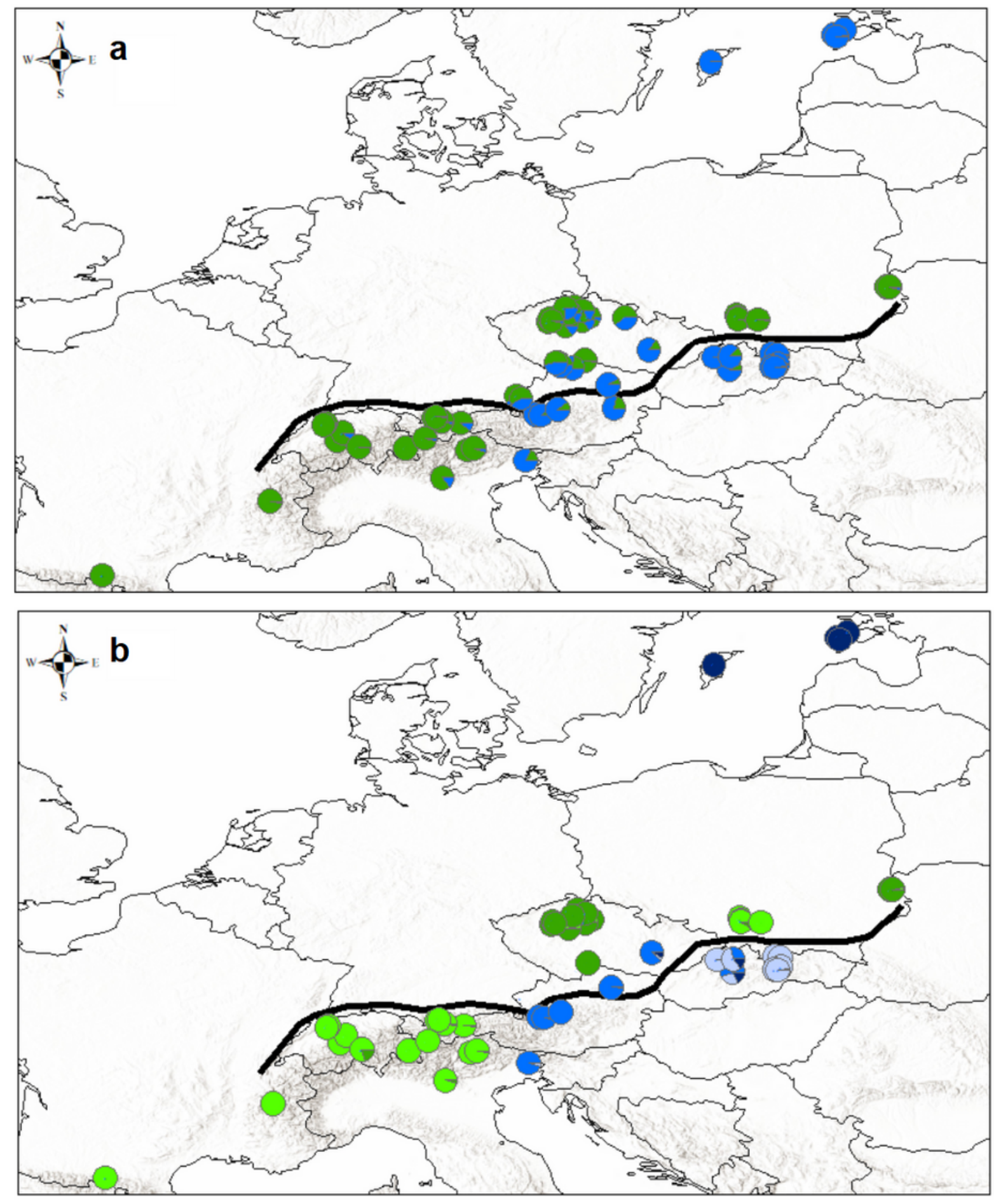

$250 \quad 500 \quad 1000$ Kilometers

Figure 1

a) Two main genetic groups of populations of T. calyculata based on STRUCTURE $(k=2), b)$ Substructure of the two main genetic groups depicted at Fig. 1a based on separate Structure analysis of the two main groups. The first (blue) group was optimally divided into three $(K=3)$, the second (green) group into two clusters $(\mathrm{K}=2)$. Black line indicates border between mountain and lowland populations. Note: The designations employed and the presentation of the material on this map do not imply the expression of 
any opinion whatsoever on the part of Research Square concerning the legal status of any country, territory, city or area or of its authorities, or concerning the delimitation of its frontiers or boundaries. This map has been provided by the authors.
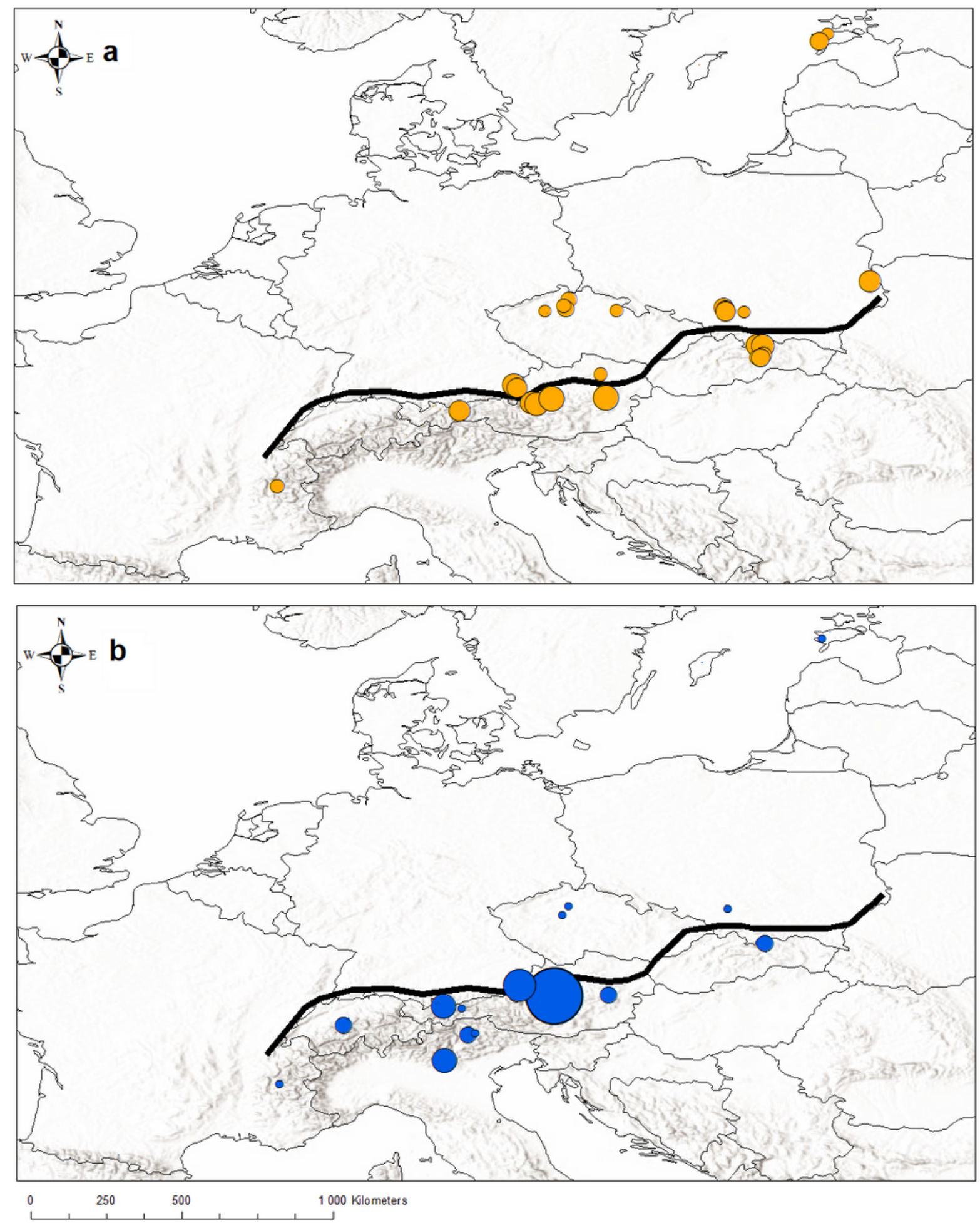

Figure 2

Distribution of a) allelic richness and b) number of unique alleles across the species range. Larger circles indicate populations with larger allelic richness and number of unique alleles (populations with 0 unique 
alleles are not shown) Black line indicates border between mountain and lowland populations. Note: The designations employed and the presentation of the material on this map do not imply the expression of any opinion whatsoever on the part of Research Square concerning the legal status of any country, territory, city or area or of its authorities, or concerning the delimitation of its frontiers or boundaries. This map has been provided by the authors.
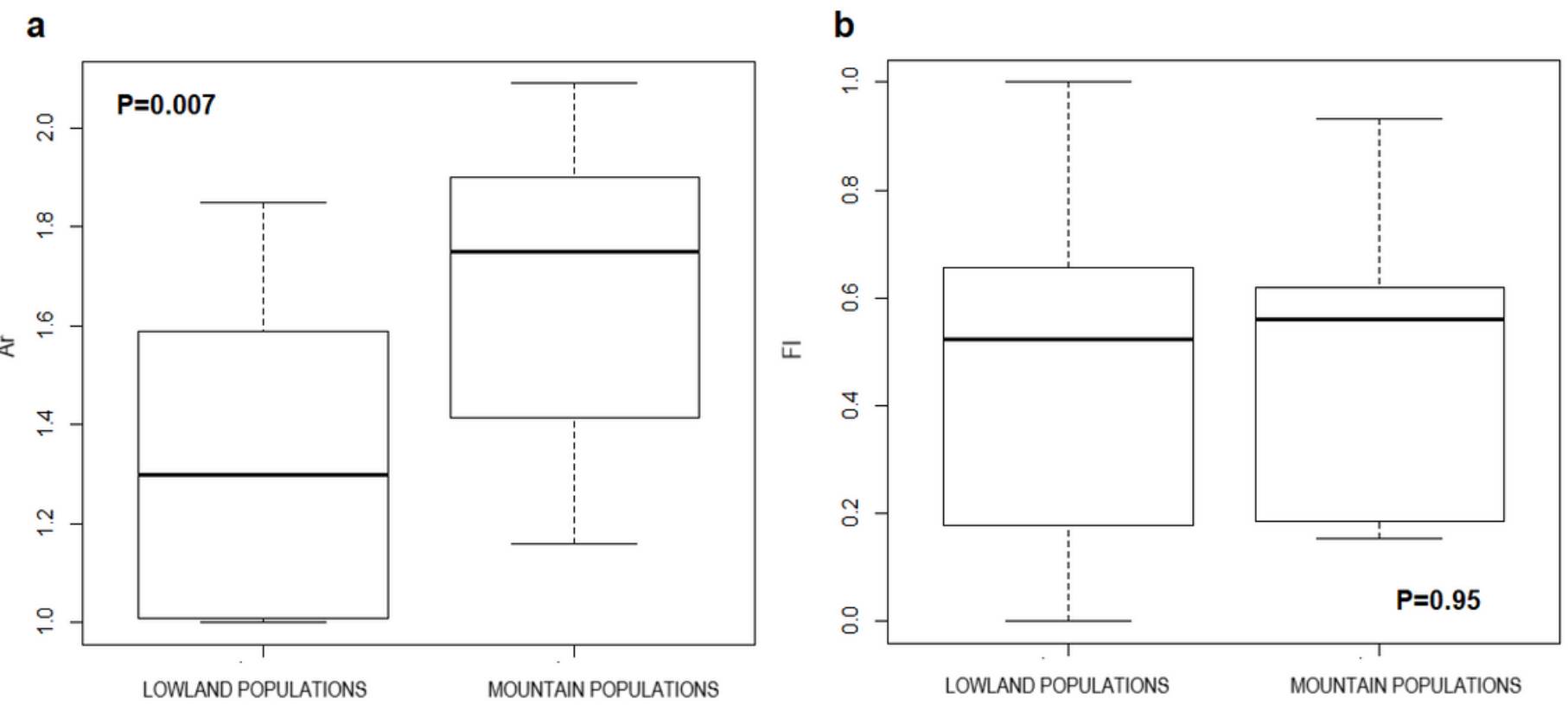

\section{Figure 3}

Comparison of $\mathrm{A}$ ) allelic richness $(\mathrm{Ar})$ and $\mathrm{B}$ ) individuals inbreeding coefficient $(\mathrm{FI})$ between lowland and mountain populations 


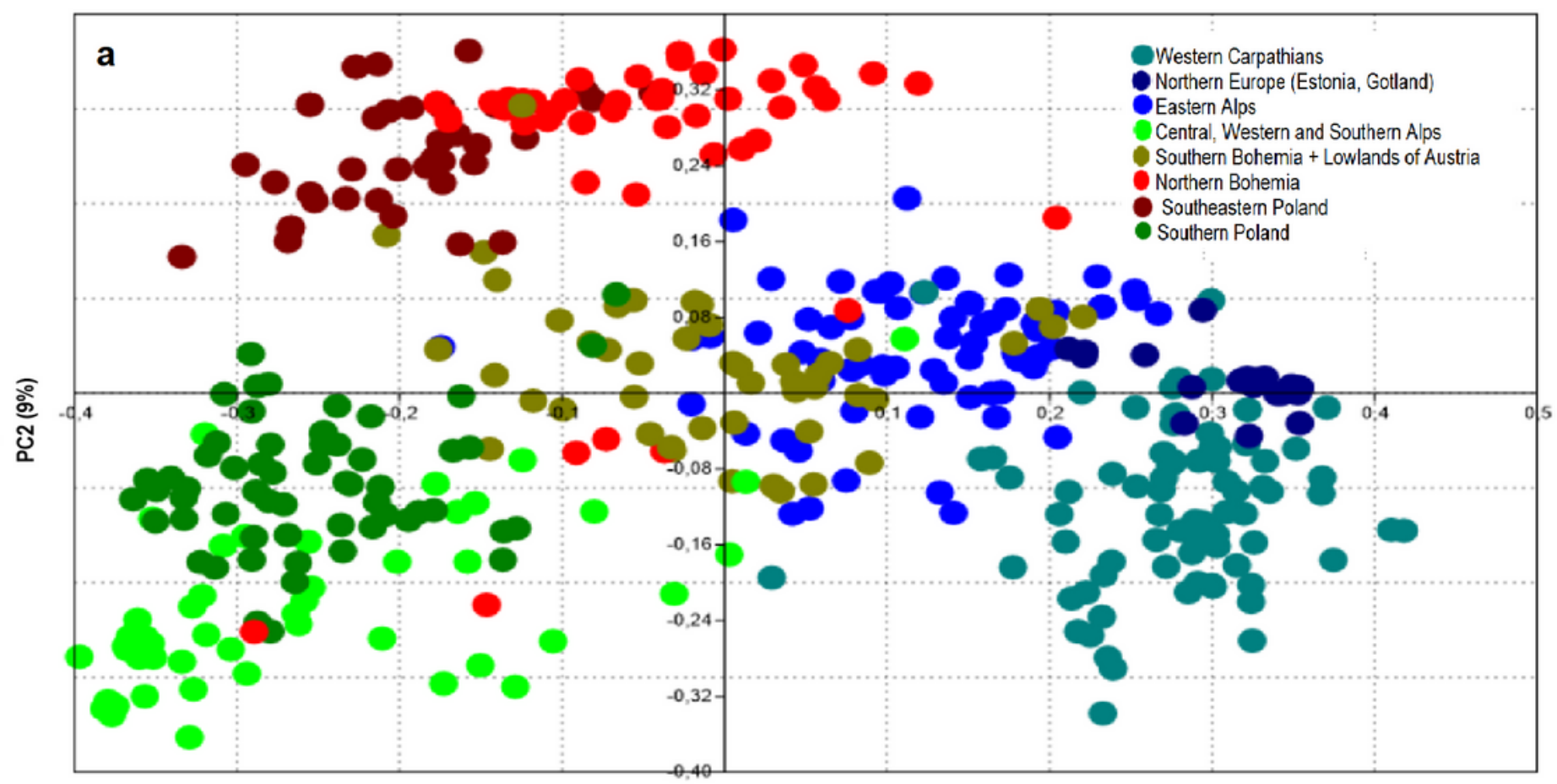

PC1 $(14.8 \%)$

GROUP 2

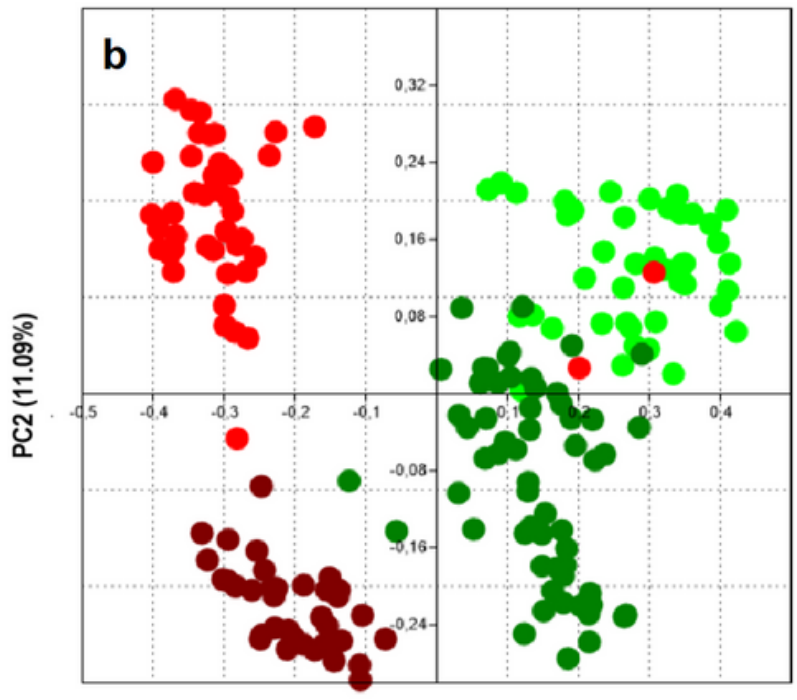

PC1 (22.89\%)

\section{GROUP 1}

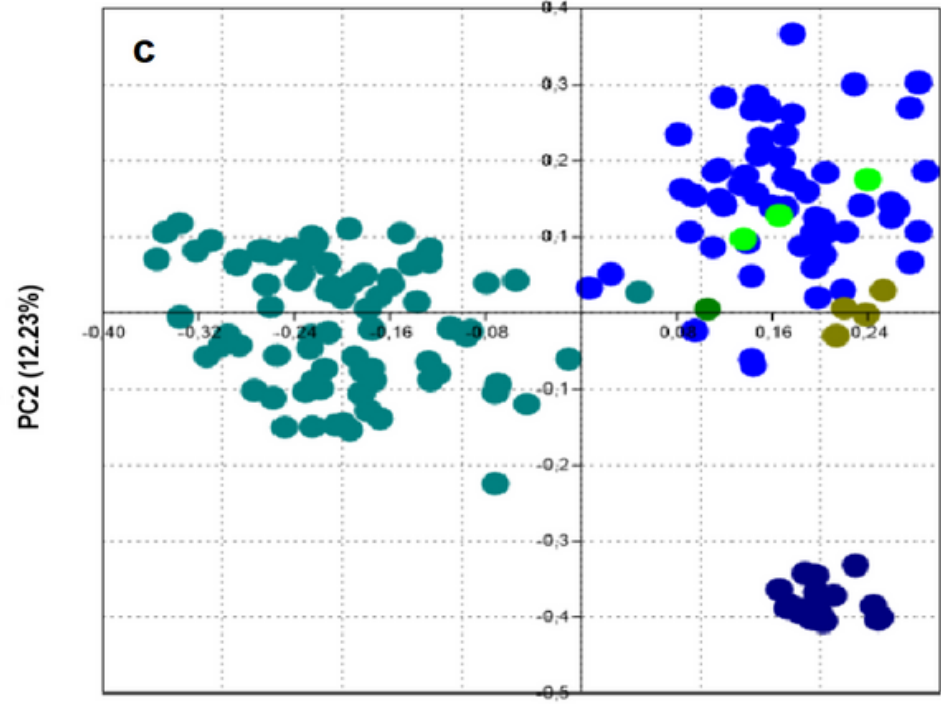

PC1 (14.53\%)

Figure 4

Results of PCoA of whole dataset (A) and separate PCoA analysis of two main groups distinguished by STRUCTURE (B, C, Fig. 3) 
- Current populations = Loss within population Loss between populations

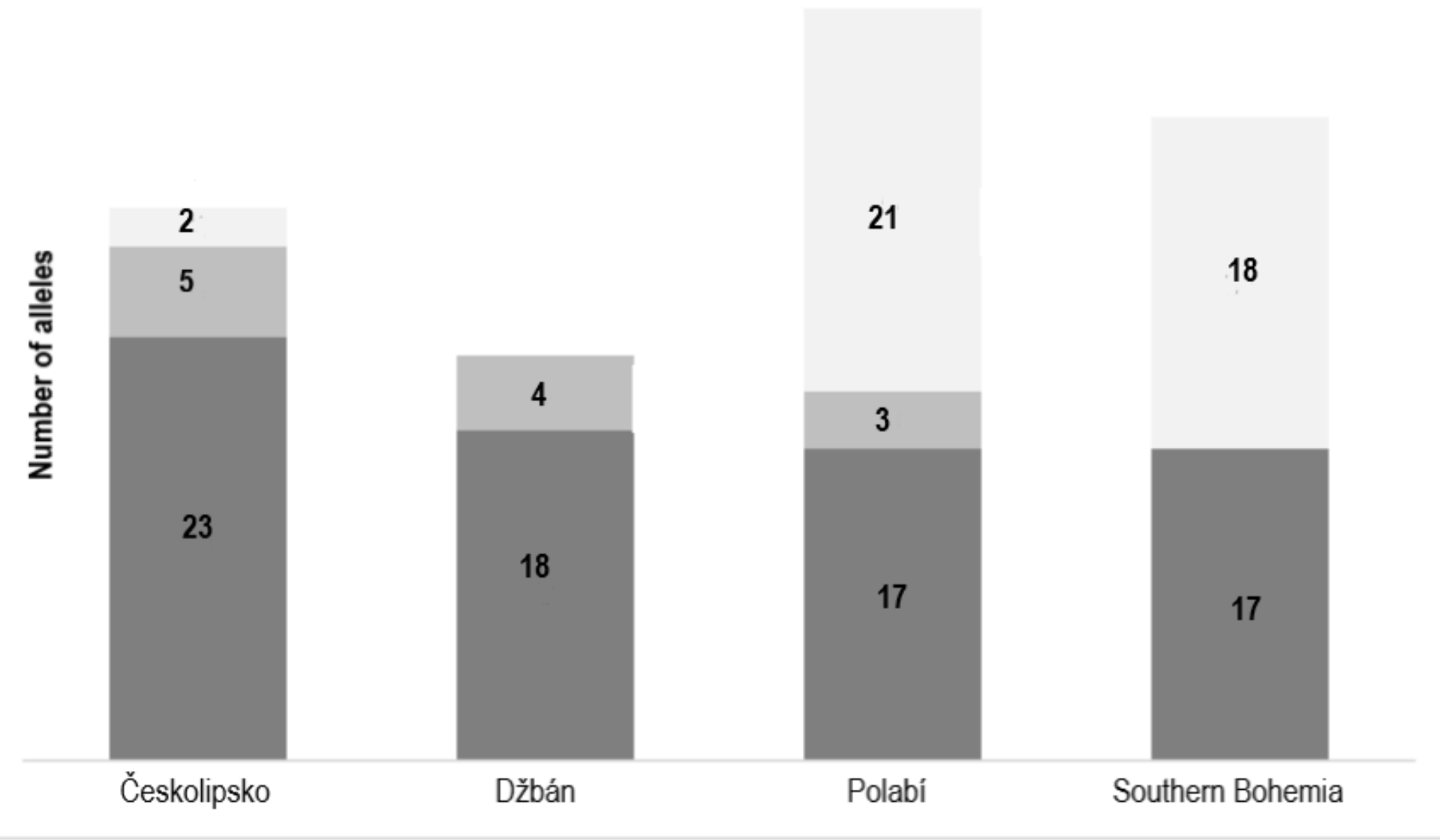

Figure 5

Loss of genetic diversity in lowland populations from the four regions from the Czech Republic. Bars indicate how many alleles survived in current populations, how many alleles have been lost on within population level and how many alleles have been lost on between populations level (due to extinction of whole populations) 


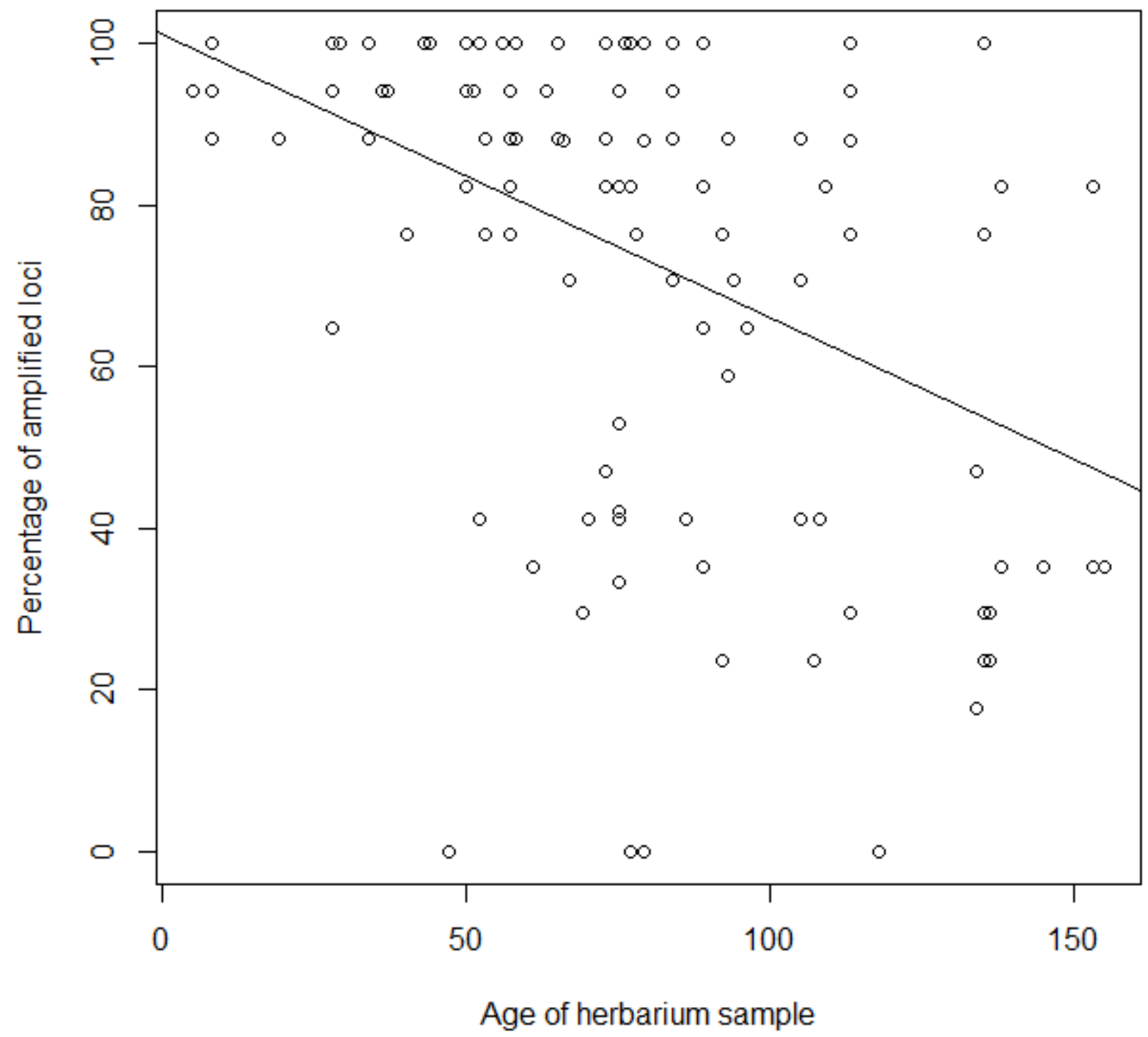

Figure 6

Relationship between age of herbaria samples and percentage of amplified loci (GLM, Explained deviance $=40.83, p<0.001$ )

\section{Supplementary Files}

This is a list of supplementary files associated with this preprint. Click to download.

- vlastasupplementarymaterial.docx 